\title{
Removal of divalent nickel from aqueous solutions using Carissa carandas and Syzygium aromaticum: isothermal studies and kinetic modelling
}

\author{
Sanjay K. Sharma ${ }^{1} \cdot$ Suresh Mahiya $^{1} \cdot$ Giusy Lofrano $^{2}$
}

Received: 1 July 2015/Accepted: 20 October 2015/Published online: 5 November 2015

(c) The Author(s) 2015. This article is published with open access at Springerlink.com

\begin{abstract}
Biosorptive removal of divalent nickel from aqueous solution using Carissa Carandas and Syzygium aromaticum was investigated in batch mode and the observations were correlated with the $\mathrm{pH}$ variation, agitation time, dose of the adsorbent and initial metal ion concentration in the solution. In the course of this study Sorption efficiency of $C$. carandas leaf powder found higher than that of $S$. aromaticum under identical experimental conditions. The maximum adsorption capacities estimated for $\mathrm{Ni}(\mathrm{II})$ through Freundlich isotherm model were 3.76 and $2.96 \mathrm{mg} / \mathrm{g}$ for C. carandas and $S$. aromaticum, respectively. In kinetic studies the correlation coefficient $\left(R^{2}=0.99\right)$ for the pseudo-second order kinetics modal was higher than that of pseudo-first order kinetics model and the calculated value of $q_{\mathrm{e}}$ for the pseudo-second order kinetic model resulted very close to the experimental value, which indicates that it fits well with the equilibrium data for $\mathrm{Ni}(\mathrm{II})$ sorption from aqueous solutions on biosorbents.
\end{abstract}

Keywords Green Chemistry · Divalent nickel · Adsorption · Biosorption · Carissa carandas - Syzygium aromaticum · Langmuir isotherm · Freundlich isotherm . Kinetics

Sanjay K. Sharma

sk.sharmaa@outlook.com

1 Green Chemistry and Sustainability Research Group, Department of Chemistry, JECRC University, Jaipur 303905, India

2 Department of Chemistry and Biology, University of Salerno, Via Giovanni Paolo II, 132, 84084 Fisciano, SA, Italy

\section{Introduction}

Heavy metal contamination of water and waste water is a widespread phenomenon mainly related to industrial activities (Volesky 2001; Saleem et al. 2015). Many plating and battery industrial, Mining, smelting activities, disposal of municipal sewage and industrial wastewater contain heavy metals such as $\mathrm{Cr}, \mathrm{Cu}, \mathrm{Cd}, \mathrm{Pb}, \mathrm{Cr}, \mathrm{Ni}, \mathrm{Hg}$ and $\mathrm{Zn}$ (Gautam et al. 2014; Denkhaus and Salnikow 2002). These heavy metals are very harmful when discharged into natural water resources and poses serious health hazard ( $\mathrm{Li}$ bralato et al. 2009a). Removal of heavy metals in water is a problem of Global concern and researchers all over the world are making tireless efforts to address this big issue with the best of their abilities and capabilities.

Among these heavy metals, Ni represents as hazardous pollutant of environmental concern, having been classified extremely toxic, embryo toxic and teratogen (Libralato et al. 2009b, 2010a, b). Nickel is the most toxic element, its higher concentration causes poisoning effects like cancer, reduction in cell growth, headache, dizziness, tightness of the chest, nausea, dry cough, chest pain, vomiting, shortness of breath, cyanosis, extreme weakness and rapid respiration (Akhtar et al. 2004). According to the World Health Organization (WHO 2006) the acceptable limit of Nickel is 0.01 and $2.0 \mathrm{mg} / \mathrm{L}$ in drinking water and industrial discharge, respectively (World Health Organization 2006).

In the last one and half decade the author (SKS) and his co-workers have also contributed significant volume of work in the field of water pollution, and applications of Green Chemistry principles in its treatment and remediation (Sharma 2003; Kulshrestha et al. 2004; Kaushik et al. 2007; Sharma et al. 2008, 2010, 2012; Yadav et al. 2008; 2010, 2011; Chandrawat et al. 2009a, b; Mudhoo et al. 
2009; Sanghi et al. 2011; Rani et al. 2011; Ozha and Sharma 2011; Mudhoo and Sharma 2011; Gautam et al. 2012).

There are many promising techniques in practice to remove heavy metals from water and have already been reported including; precipitation (Esalah et al. 2000), flotation (Zouboulis et al. 1997), biosorption (Mahiya et al. 2014; Ho et al. 2001), membrane separation (Canet et al. 2002), adsorption on minerals (Buerge-Weirich et al. 2002; Ahmed et al. 2002; Chamila et al. 2015), Zeolites (Pankaj et al. 2015) and activated carbon (Khan et al. 2015; Ravindran et al. 1999). Many researchers also use Bacteria, fungi and algae for removal of heavy metals (Ankur and Chandrajit 2015; Hossein et al. 2015).

Green Chemistry plays a very important and vital role in removal of metal ions from water. There are some commonly applied green techniques including phytoremediation, bioremediation, use of functionalized magnetic nanoparticles, photocatalytic processes and biosorption using industrial and agricultural waste as a biosorbent have been developed in recent years. Adsorption, a physicochemical process where the adsorbate accumulates at the interface of adsorbent, has become a useful green technique and attracts eyeballs worldwide (Grassi et al. 2012). Biosorption have many certain advantages including low cost and high efficiency, minimization of chemical and biological sludge, and possibility of metal recovery and most important regeneration of biosorbent.

Several investigations have been carried out to identify suitable and relatively cheap biosorbents that are capable of removing significant quantities of nickel(II) ions. Successful metal biosorption has been reported by a variety of biological materials including Trachyspermum copticum (Ajwain) (Rifaqat and Shaista 2015), Modified Chitosan (Ma et al. 2014), Farfantepenaeus aztecus (shrimp) biomass (Alejandro and Eliseo 2014), rice bran (Muhammad et al. 2015), Nannorrhops ritchiana (Mazri Palm) (Sefath et al. 2014), Lycopersicum esculentum (Tomato) (Yuvaraja et al. 2015).

Earlier, we have carried out biosorptive removal of divalent copper from aqueous solution using Carissa carandas and Syzygium aromaticum (Mahiya et al. 2014). In which, adsorption of $\mathrm{Cu}$ (II) onto $S$. aromaticum was best described by the Langmuir isotherm modal and the maximum adsorption capacities estimated for $\mathrm{Cu}$ (II) were 54.2 and $76.61 \mathrm{mg} / \mathrm{g}$ for $C$. carandas and $S$. aromaticum, respectively. Results of that study encouraged us to try the same adsorbents for removal of divalent nickel this time.

The purpose of the present research was to evaluate the efficiency of $C$. carandas and S. aromaticum as biosorbents for removal of divalent nickel from water. Maximum adsorption capacity of biosorbents, the adsorption intensity of the adsorbate on biosorbents surface and biosorption potentials of biosorbents was estimated by Langmuir and Freundlich isotherms, respectively. Batch adsorption experiments for removal of $\mathrm{Ni}(\mathrm{II})$ were carried out at ambient temperature $\left(30^{\circ} \mathrm{C}\right)$ as a function of solution $\mathrm{pH}$ (2-12), biosorbent dosage $(2-10 \mathrm{~g} / 100 \mathrm{~mL})$, contact time (with a time interval of every $60 \mathrm{~min}$ ) up to $300 \mathrm{~min}$ and initial metal ion concentration. Then, equilibrium isotherms and kinetic data parameters were evaluated. The sorption efficiency of adsorbents was explained with help of SEM image visualization and FTIR analysis.

\section{Materials and methods}

\section{Chemicals}

Analytical-grade chemicals were used in this work without further purification. To avoid any interference of other ions, all solutions were prepared using double distilled water. $\mathrm{Ni}(\mathrm{II})$ was prepared by dissolving $4.783 \mathrm{~g}$ of $\mathrm{NiSO}_{4} \cdot 5 \mathrm{H}_{2} \mathrm{O}$ in $1000 \mathrm{~mL}$ volumetric flask and make up to the mark with double distilled water. All the required working solutions were prepared as per the reported method in earlier study of the present researchers (Mahiya et al. 2014). Dilute solutions of $1 \mathrm{M} \mathrm{HCl}$ and $1 \mathrm{M} \mathrm{NaOH}$ were used to adjust $\mathrm{pH}$ of metal ion solutions using a $\mathrm{pH}$ meter.

\section{Adsorbent}

The leaves of $C$. carandas were collected from local field of Pushkar (India) and the buds of S. aromaticum were collected from local market of Jaipur (India). The leaves of $C$. carandas and the buds of $S$. aromaticum were extensively washed with running tap water for remove dirt and other particulate matter then washed by double distilled water and dried in sunlight, then at $60{ }^{\circ} \mathrm{C}$ for $24 \mathrm{~h}$ in hot air oven. Finally, the dried leaves of $C$. carandas and $S$. aromaticum were grinded in clean electric mixer and stored in a dry and clean plastic bag.

\section{Adsorption experiment}

Batch adsorption studies were performed at room temperature. The adsorption equilibrium experiments for $\mathrm{Ni}(\mathrm{II})$ solution were carried out by taking $100 \mathrm{~mL}$ of nickel solution in $250 \mathrm{~mL}$ conical flask and then the flasks were agitated at $200 \mathrm{rpm}$ in an incubator. At the end of predefined time intervals, the flasks were withdrawn from shaker, filtered by What man filter paper No. 41 and the supernatant solutions were analysed for $\mathrm{Ni}(\mathrm{II})$ ion concentration using an Atomic Absorption Spectrometer (Thermo scientific Solar S-series AA Spectrometer). 


\section{Results and discussion}

\section{Characterization of biosorbent by gas chromatography-mass spectroscopy}

Gas Chromatography-Mass Spectroscopy (GC-MS) is one of the best techniques to identify the constituents of volatile matter, long chain, branched chain hydrocarbons, alcohols acids and esters etc. The GC-MS analysis of $C$. carandas leaves and $S$. aromaticum revealed the presence of 43 and 40 active compounds, respectively. The identification of the phytochemical compounds was confirmed based on the peak area, retention time and molecular formula.
Gas chromatography-mass spectroscopy analysis of $S$. aromaticum The $S$. aromaticum buds were analysed by GC-MS and eugenol identified as a major constituent. In the clove bud essential oil eugenol acetate is the second major component. The Results Revealed that, Phenol, 2-Methoxy-4-(2-Propenyl)- (Eugenol) (46.01\%), Phenol, 2-Methoxy-4-(2-Propenyl)-, Acetate (Eugenol Acetate) (23.42\%), Bicyclo[7.2.0]Undec-4-Ene, 4,11,11-Trimethyl-8-Methylene- (12.43\%), 1,4,8-Cycloundecatriene, 2,6,6,9-Tetramethyl (3.00\%), 6-Octadecenoic Acid, (Z)(2.18), (-)-5-Oxatricyclo[8.2.0.0(4,6)]Dodecane, 12-Trimethyl-9-Methylene- (2.00), Benzoic Acid, 2-Hydroxy-, Methyl Ester (0.11\%), 4-Allylphenol (0.88 \%), Benzene,
Fig. 1 GC-MS spectra of $C$. carandas

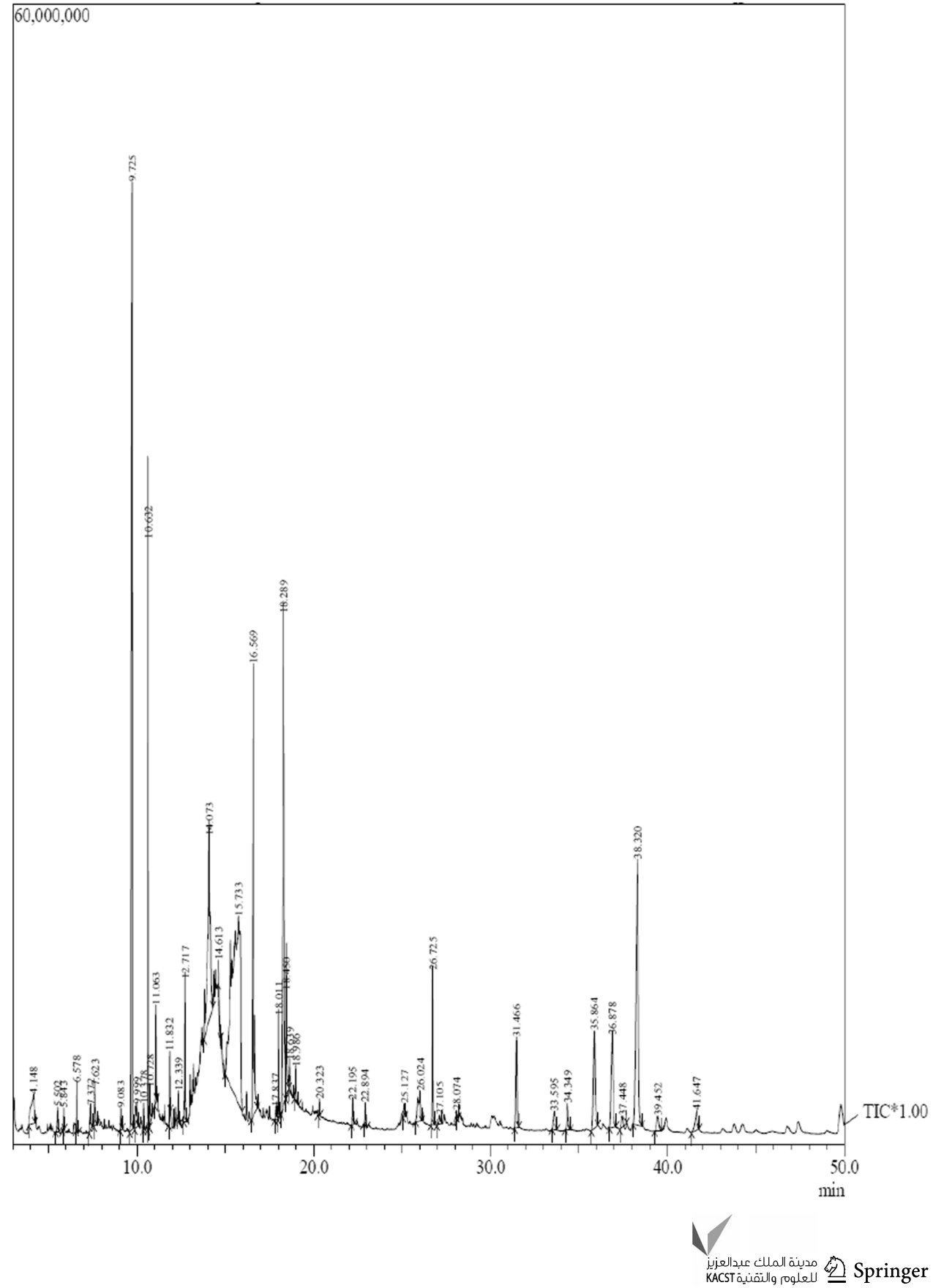


1-Methoxy-4-(1-Propenyl)- (0.13\%), 2-Acetyl-2-Methylphenyl Acetate $(0.22 \%), 1,2,3$-Benzenetriol (1.58 \%), Naphthalene, 1,2,3,4,4a,5,6,8a-Octahydro-7-Methyl-4Methylene-1-(1-Methylethyl)- $(0.13 \%), \quad 1,3,6,10$-Dodecatetraene, 3,7,11-Trimethyl- (0.53\%), 1-(4-Isopropoxy-3Methoxyphenyl)Acetone $(0.09 \%)$, Dodecanoic Acid $(0.12 \%)$, Epi-Alpha-Patschulene $(0.19 \%)$, Phenol, 2-Methoxy-4-(2-Propenyl)-, Acetate $(0.11 \%), 12-O x a b i-$ cyclo[9.1.0]Dodeca-3,7-Diene, 1,5,5,8-Tetramethyl$(0.16 \%)$, 1-Naphthalenol, 1,2,3,4,4a,7,8,8a-Octahydro1,6-Dimethyl-4-(1-Methylethyl)- $(0.31 \%), \quad 4-(2,6,6-T r i-$ methyl-Cyclohex-1-Enyl)-Butyric Acid $(0.13 \%), 4-((1 \mathrm{e})-$ 3-Hydroxy-1-Propenyl)-2-Methoxyphenol $(0.36 \%)$ 4-(2,6,6-Trimethyl-1-Cyclohexen-1-Yl)-2-Buta $(0.16 \%)$, 10-Methoxy-Nb-.Alpha.-Methylcorynantheol $\quad(0.10 \%)$,
4,4,8-Trimethyl-Tricyclo[6.3.1.0 1,5]Dodecane- (0.18\%), L-(+)-Ascorbic Acid 2,6-Dihexadecanoate (1.61\%), 1,2Benzenedicarboxylic Acid, Dibutyl Ester (0.25\%), Octadecanoic Acid (0.12 \%), Cyclobutane, 3-Hexyl-1,1,2Trimethyl-, Cis- $(0.11 \%), \quad 1,13$-Tetradecadien-3-One (0.07 \%), Octadecanoic Acid, Ethyl Ester (0.07 \%), 3-(4-PTolyl-Thiazol-2-Yl)-4,5,6,7-Tetrahydro-Benzo[B]Thiophen-2-Ylamine $(0.29 \%)$, Capsaicin $(0.10 \%)$, Dihydrocapsaicin $(0.06 \%)$, E,Z-1,3,12-Nonadecatriene $(0.20 \%)$, Phenol, 2-Methoxy-4-(1-Propenyl)- $(0.20 \%)$, Squalene $(0.15 \%)$, Vitamin E $(0.28 \%)$, Stigmast-5-En-3-Ol, (3.Beta.)- $(1.52 \%)$, Tetracyclo[5.4.3.0(7,11)]Tetradeca2,5,10-Trione, 1,4,6,14-Tetramethyl-4-Vinyl- (0.17\%), Benzyl Myristate $(0.27 \%)$ and other compounds are available in it.
Fig. 2 GC-MS spectra of $S$. aromaticum

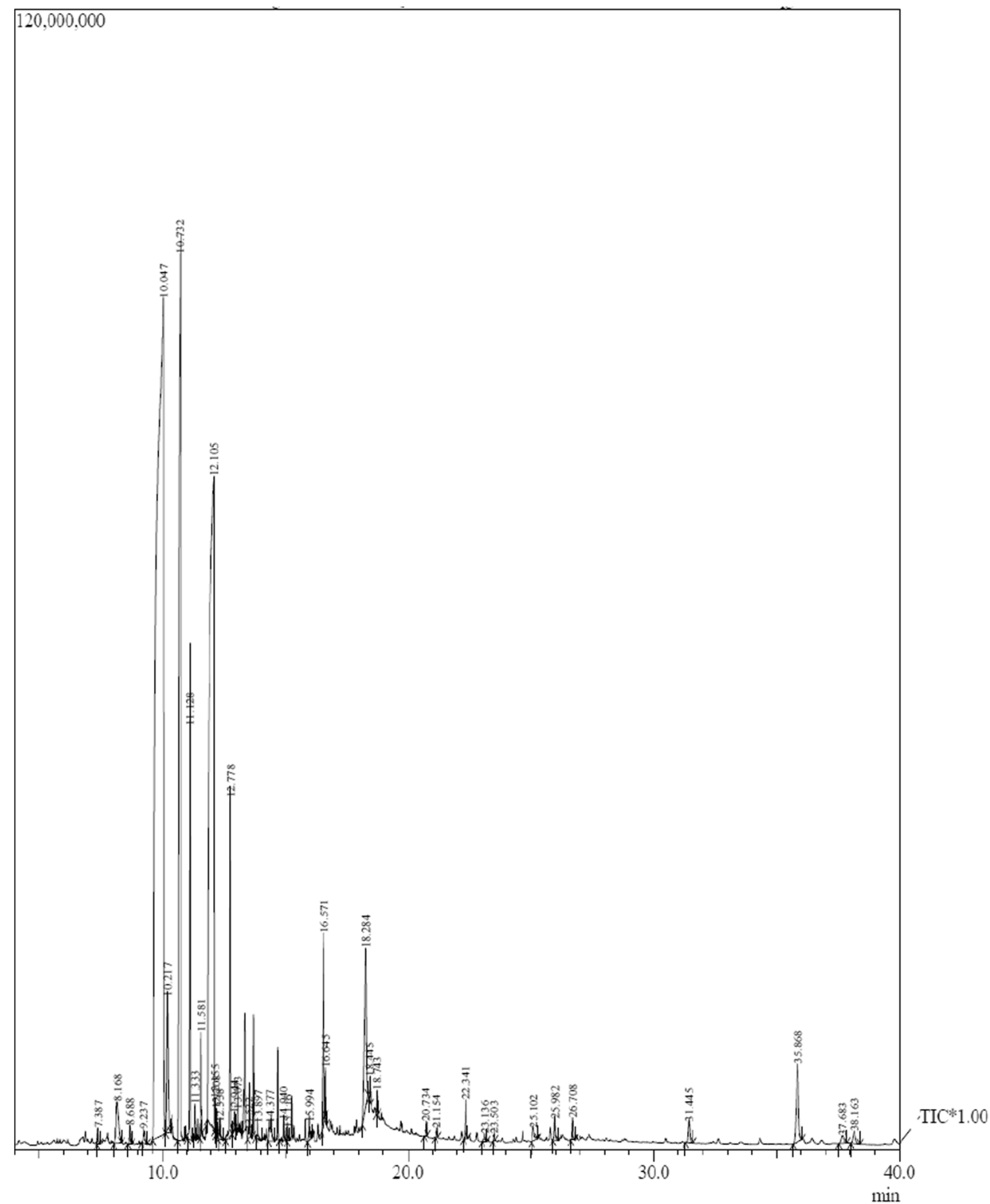


Gas chromatography-mass spectroscopy analysis of $C$. carandas It shows the presence of Mome Inositol (23.69\%), Phenol, 2-Methoxy-4-(2-Propenyl)- (12.52\%), Cis-9-Hexadecenal (10.97 \%), 1,2,3-PROPANETRIOL $(1.31 \%)$, 1,3,5-Triazine-2,4,6-Triamine (0.32\%), Oxetane, 2-Propyl- (0.20\&), 4 h-1,3,2-Dioxazine-2-Acetic Acid, Dihydro-.Alpha. (0.43\%), 4-(1-HydroxyEthyl).Gamma.Butanolactone $(0.37 \%), 2,3$-Dihydro-Benzofuran $(0.48 \%)$, 2-Methoxy-4-Vinylphenol $(0.21 \%)$, Tricyclo[4.4.0.0(2,7)]Dec-3-Ene, 1,3-Dimethyl-8-(1Methylethyl)-, St (0.67\%), 1h-Cycloprop[E]Azulene, 1a,2,3,4,4a,5,6,7b-Octahydro-1,1,4,7-Tetramethyl-, [1ar(1a.Alpha.,4.Alpha.,4a.Be (0.17\%), Bicyclo[7.2.0]Undec4-Ene, 4,11,11-Trimethyl-8-Methylene-, [1r-(1r*,4e,9s*)](4.68\%), 3,5-Dimethylanisole $(0.42 \%)$, 1,4,7,-Cycloundecatriene, 1,5,9,9-Tetramethyl-, Z,Z,Z- (0.67\%), Phenol, 2-Methoxy-4-(2-Propenyl)-, Acetate (0.41\%), 4-Methyl2,5-Dimethoxybenzaldehyde $\quad(0.18 \%)$, 5-Oxatricyclo[8.2.0.0(4,6)]Dodecane,12-Trimethyl-9-Methylene(1.18\%), L-(+)-Ascorbic Acid 2,6-Dihexadecanoate (7.15\%), 9,12-Octadecadienoic Acid (Z,Z)-, Methyl Ester (0.29\%), 2-Hexadecen-1-Ol, 3,7,11,15-Tetramethyl-, [R$\left.\left[\mathrm{R}^{*}, \mathrm{R}^{*}-(\mathrm{E})\right]\right]-(0.78 \%)$, Octadecanoic Acid (1.46\%), 9,12Octadecadienoic Acid (0.43\%), 9,12-Octadecadienoic Acid (Z,Z)- (0.42\%), 4,8,12,16-Tetramethylheptadecan-4-Olide $(0.12 \%)$, Hexadecanoic Acid, 2-Hydroxy-1-(Hydroxymethyl)Ethyl Ester (0.35\%), 10-Methyldodec-2-En-4Olide $(0.26 \%)$, Oleoyl Chloride $(0.20 \%), 10$-Methyldodec2-En-4-Olide $(1.19 \%)$, Squalene (1.56\%), 1-Pyrrolidinebutanoic Acid, 2-[(1,1-Dimethylethoxy)Carbonyl].Alpha.-Nitro-, 2,6-Bis(1,1-Dimethylethyl)-4-Methoxyphenyl Ester, [S-(R*,R*)]- (0.20\%), Vitamin E (1.59\%), ERGOST-5-EN-3-OL, (3.BETA.,24R)- (0.51\%), Stigmasterol (0.64\%), STIGMAST-5-EN-3-OL, (3.BETA.)$(2.55 \%)$,.Beta.-Amyrin $(2.77 \%), 1 \mathrm{H}-3 \mathrm{a}, 7-M e t h a n o a z u l e n-$
6-Ol, Octahydro-3,6,8,8-Tetramethyl-, Acetate, [3R-(3.Alpha.,3a.Beta.,6.Alpha.,7.Beta.,8a.Alpha.)]- $\quad(0.17 \%)$, Lupeol (9.92 \%),.Alpha.-Tocopherol-.Beta.-D-Mannoside (0.48\%), Lup-20(29)-En-3-Yl Acetate (0.81\%).

The whole FTIR discussion about $C$. carandas and $S$. aromaticum reported in previous study (Figs. 1 and 2) seems well according to the reported absorption data of various expected groups present in $C$. carandas and $S$. aromaticum (Silverstein et al. 1981) and supported by the given data of GC-MS analysis. However, the exact functional groups, their native at adsorption mechanism and site of bonding between various functional groups present and $\mathrm{Ni}$ (II) are yet to be explored for better understanding of whole absorption process which will be surely an interesting objective in our future experiments and publications.

\section{Effect of pH on biosorption}

The effect of $\mathrm{pH}$ on the removal of divalent nickel was studied and it was observed that the metal sorption is

Table 1 Effect of solution $\mathrm{pH}$ on biosorption of $\mathrm{Ni}(\mathrm{II})$ by $C$. carandas and $S$. aromaticum

\begin{tabular}{lrll}
\hline S. No. & $\mathrm{pH}$ & \multicolumn{2}{l}{ Removal of Ni(II) $(\%)$} \\
\cline { 3 - 4 } & & Carissa carandas & Syzygium aromaticum \\
\hline 1 & 2 & 42 & 37 \\
2 & 4 & 75 & 59 \\
3 & 6 & 85 & 74 \\
4 & 8 & 79 & 66 \\
5 & 10 & 68 & 58 \\
6 & 12 & 53 & 51 \\
\hline$C_{0}=100 \mathrm{ppm}$, & dosage $=2 \mathrm{~g} / 100 \mathrm{~mL}$, contact time $=180 \mathrm{~min}$, \\
$T=300 \mathrm{~K}$ &
\end{tabular}

Fig. 3 Effect of solution $\mathrm{pH}$ on biosorption of $\mathrm{Ni}$ (II) by $C$. carandas and $S$. aromaticum $\left(C_{0}=100 \mathrm{ppm}\right.$, dosage $=2 \mathrm{~g} /$ $100 \mathrm{~mL}$, contact time $=180 \min , T=300 \mathrm{~K}$ )

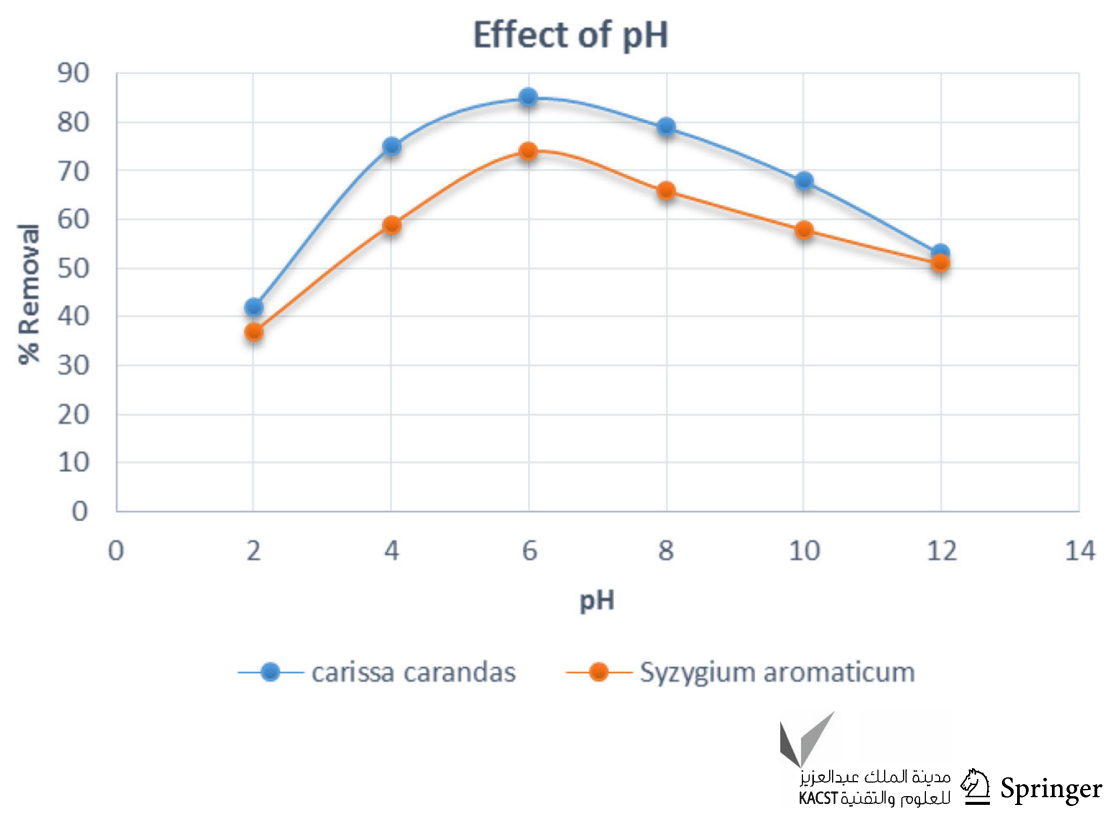


Fig. 4 Effect of contact time on biosorption for $\mathrm{Ni}(\mathrm{II})$ by $C$. carandas and $S$. aromaticum $\left(C_{0}=100 \mathrm{ppm}\right.$, dosage $=2 \mathrm{~g} /$ $100 \mathrm{~mL}, \mathrm{pH} 6, T=300 \mathrm{~K}$ )

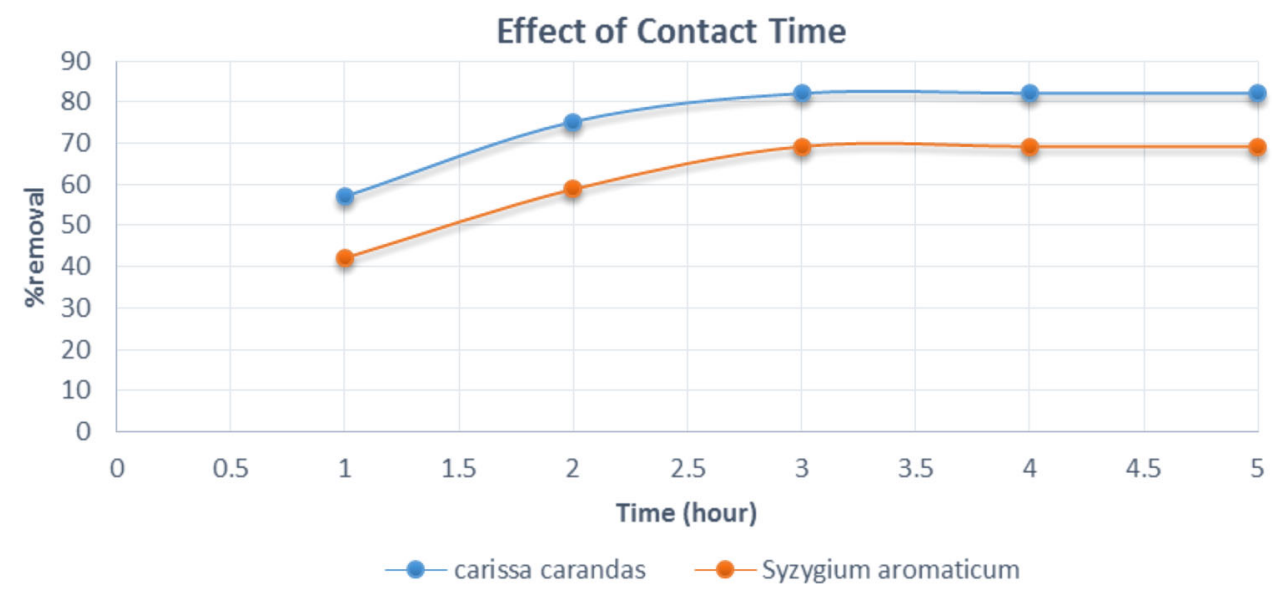

Table 2 Effect of contact time on biosorption for $\mathrm{Ni}$ (II) by $C$. carandas and $S$. aromaticum

\begin{tabular}{llll}
\hline S. No. & $\begin{array}{l}\text { Contact } \\
\text { time }(\mathrm{min})\end{array}$ & \multicolumn{2}{l}{ Removal of Ni(II) $(\%)$} \\
\cline { 3 - 4 } & $\begin{array}{l}\text { Carissa } \\
\text { carandas }\end{array}$ & $\begin{array}{l}\text { Syzygium } \\
\text { aromaticum }\end{array}$ \\
\hline 1 & 60 & 56.91 & 42.11 \\
2 & 120 & 75.23 & 58.84 \\
3 & 180 & 82.22 & 69.23 \\
4 & 240 & 82.22 & 69.23 \\
5 & 300 & 82.22 & 69.23 \\
\hline
\end{tabular}

$C_{0}=100 \mathrm{ppm}$, dosage $=2 \mathrm{~g} / 100 \mathrm{~mL}, \mathrm{pH} 4$, temp $=300 \mathrm{~K}$

critically linked with $\mathrm{pH}$ and it was found that the $\mathrm{pH}$ of the solution is a very important controlling and contributing factor in the adsorption process. The effect of $\mathrm{pH}$ was studied at $100 \mathrm{mg} / \mathrm{L} \mathrm{Ni}(\mathrm{II})$ concentration, biosorbent dosage of $2 \mathrm{~g} / 100 \mathrm{~mL}$ at the $\mathrm{pH}$ range 2-12. According to Fig. 3 the percentage of $\mathrm{Ni}(\mathrm{II})$ removal increased with the increase in the $\mathrm{pH}$ up to the $\mathrm{pH}$ 6. After $\mathrm{pH}$ 6, further increase in $\mathrm{pH}$ value decrease the percentage of $\mathrm{Ni}$ (II) removal (Table 1; Fig. 3) possibly due to the formation of soluble hydroxide complexes of $\mathrm{Ni}(\mathrm{II})$, which competes with the biosorption of Ni(II) by biomass. Similar results of the effect of $\mathrm{pH}$ on the biosorption have also been observed earlier for $\mathrm{Ni}$ (II) biosorption using dried green alga (Aksu and Dönmez 2006), activated sludge (Ajay Kumar et al. 2009), waste tea material (Aikpokpodion et al. 2010) and coconut copra meal (Saleem et al. 2015); which strengthen our point of view.

\section{Effect of contact time on biosorption}

Effect of contact time on biosorption was studied for designing batch biosorption experiments. Contact time between biosorbent and adsorbate play a key role in influencing the biosorption process (Saleem et al. 2015). As shown in Fig. 4 the biosorption efficiency of $\mathrm{Ni}$ (II) increased substantially until the contact time reached at $180 \mathrm{~min}$ and then it proceeds at slower rate of increases and finally attained saturation. So, the optimum contact time was selected as $180 \mathrm{~min}$ for further experiments. The equilibrium time was independent of adsorbent type. The $\mathrm{Ni}$ (II) adsorption rate at the initial stage depends on increased availability in the number of active binding sites on the adsorbent surface. At later stage, no significant sorption takes place due to non-availability of sorption sites. Therefore, further experiments were carried out at $180 \mathrm{~min}$ as a significant contact time for Ni(II) adsorption (Table 2; Fig. 4).

\section{Effect of Biosorbent Dose}

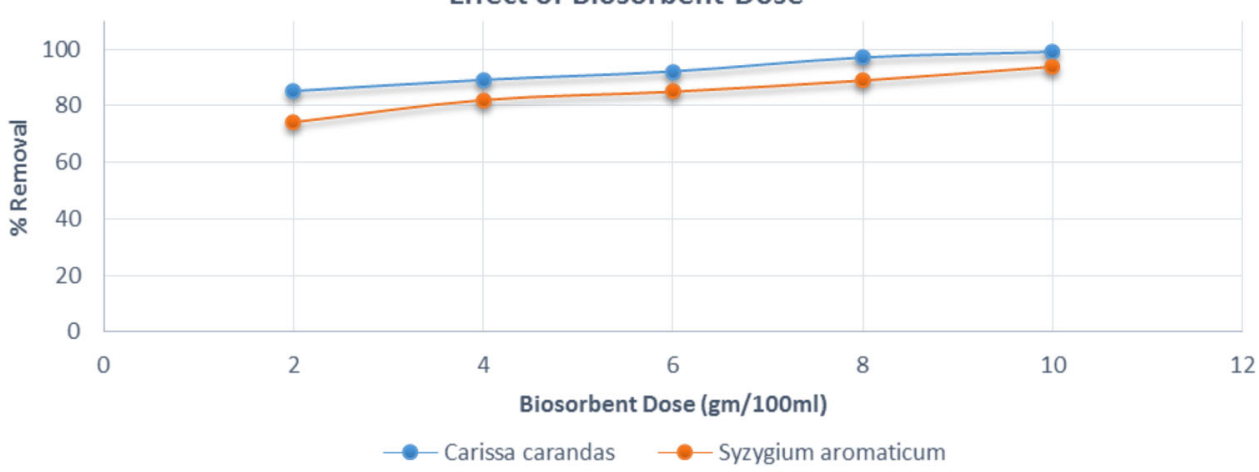

Fig. 5 Effect of biosorbent dose on biosorption capacity of $\mathrm{Ni}(\mathrm{II}) ;\left(C_{0}=100 \mathrm{mg} / 100 \mathrm{~mL}\right.$, contact time $=180 \mathrm{~min}, \mathrm{pH} 6$, $T=300 \mathrm{~K})$ 
Table 3 Effect of biosorbent dosage on biosorption capacity of $\mathrm{Ni}(\mathrm{II})$

\begin{tabular}{|c|c|c|c|}
\hline \multirow[t]{2}{*}{ S. No. } & \multirow{2}{*}{$\begin{array}{l}\text { Biosorbent } \\
(\mathrm{g} / 100 \mathrm{~mL})\end{array}$} & \multicolumn{2}{|c|}{ Removal of $\mathrm{Ni}(\mathrm{II})(\%)$} \\
\hline & & $\begin{array}{l}\text { Carissa } \\
\text { carandas }\end{array}$ & $\begin{array}{l}\text { Syzygium } \\
\text { aromaticum }\end{array}$ \\
\hline 1 & 2 & 85 & 74 \\
\hline 2 & 4 & 89 & 82 \\
\hline 3 & 6 & 92 & 85 \\
\hline 4 & 8 & 97 & 89 \\
\hline 5 & 10 & 99 & 94 \\
\hline
\end{tabular}

$C_{0}=100 \mathrm{ppm} / 100 \mathrm{~mL}$, contact time $=180 \mathrm{~min}, \mathrm{pH} 6, T=300 \mathrm{~K}$

\section{Effect of biosorbent dose}

As shown in Fig. 5 the effect of biomass dosage on the $\mathrm{Ni}$ (II) biosorption was studied using different doses ranging from 2 to $10 \mathrm{~g} / 100 \mathrm{~mL}$. An increase in nickel removal from 85 to $99 \%$ for C. carandas and from 74 to $94 \%$ for S. aromaticum (Table 3; Fig. 5) was observed with increasing biomass concentration $(2-10 \mathrm{~g} / 100 \mathrm{~mL})$.

\section{Effect of initial metal concentration}

The effect of initial concentration of $\mathrm{Ni}$ (II) metal and its removal using $C$. carandas and $S$. aromaticum biomass is shown in Fig. 6. The biosorbents dose, $\mathrm{pH}$ and contact time for the batch experiment were found best recorded at $2 \mathrm{~g} /$ $100 \mathrm{~mL}, \mathrm{pH} 6$ and $180 \mathrm{~min}$, respectively.

By increasing the initial concentration of $\mathrm{Ni}$ (II) in a batch study, a saturation point appears which resulted in decreased percentage of $\mathrm{Ni}$ (II) removal (Saleem et al. 2015). In batch study using $C$. carandas and $S$. aromaticum biomass percentage removal of $\mathrm{Ni}$ (II) decreased from 82.22 to $38.16 \%$ and 69.23 to $34.49 \%$ when the initial concentration of Ni was increased from 100 to $1000 \mathrm{mg} / \mathrm{L}$ (Table 4; Fig. 6).

\section{Effect of temperature}

Figure 7 shows the biosorption of $\mathrm{Ni}$ (II) for varied temperatures at $180 \mathrm{~min}$ of contact time. As shown in Fig. 7 biosorption capacities were found for $\mathrm{Ni}(\mathrm{II})$ at $20,30,40$ and $60{ }^{\circ} \mathrm{C}$ as 56.76, 82.22, 69.17 and $61.53 \mathrm{mg} / 100 \mathrm{~mL}$ for C. carandas and $52.12,69.23,65.91,54.15 \mathrm{mg} / 100 \mathrm{~mL}$ for $S$. aromaticum, respectively. The biosorption capacities of C. carandas and $S$. aromaticum were best recorded at $30{ }^{\circ} \mathrm{C}$. The decrease in biosorption capacity of $C$. carandas and $S$. aromaticum above $30^{\circ} \mathrm{C}$ may be attributed to the deactivation of the biosorbent surface or the destruction of some active sites on the biosorbent surface. As a result, the optimum temperature for $\mathrm{Ni}$ (II) biosorption was chosen as $30{ }^{\circ} \mathrm{C}$ for subsequent experiments (Table 5).

\section{Isothermal studies}

To better understanding of the Ni(II) ion adsorption to the Carissa carandas and $S$. aromaticum, we first analysed the adsorption isotherms that give comprehensive information about the nature of interaction. The adsorption isotherm shows that adsorbate $\left(C_{\mathrm{e}}\right)$ interacts with adsorbent $\left(q_{\mathrm{e}}\right)$ at a constant temperature and reflects the nature of adsorption reaction (Mondal et al. 2013).

To determine the surface properties of adsorbents and its affinity with nickel, the isotherm data were tried to different isotherm models. In this research, biosorption isotherm study was carried out on two well-known 'twoparameter isotherms', namely Langmuir and Freundlich isotherms. The well-known expression of Langmuir isotherm model (Langmuir 1918) is presented in Eq. 1

$q_{\mathrm{e}}=Q_{0} b C_{\mathrm{e}} /\left(1+b C_{\mathrm{e}}\right)$,

where $C_{\mathrm{e}}(\mathrm{mg} / \mathrm{L})$ and $q_{\mathrm{e}}(\mathrm{mg} / \mathrm{g})$ are the liquid phase concentration and solid phase concentration of adsorbate at
Fig. 6 Effect of initial metal concentration on biosorption of $\mathrm{Ni}(\mathrm{II})$; (Dosage $=2 \mathrm{~g} / 100 \mathrm{~mL}$, contact time $=180 \mathrm{~min}, \mathrm{pH} 6$, $T=300 \mathrm{~K})$

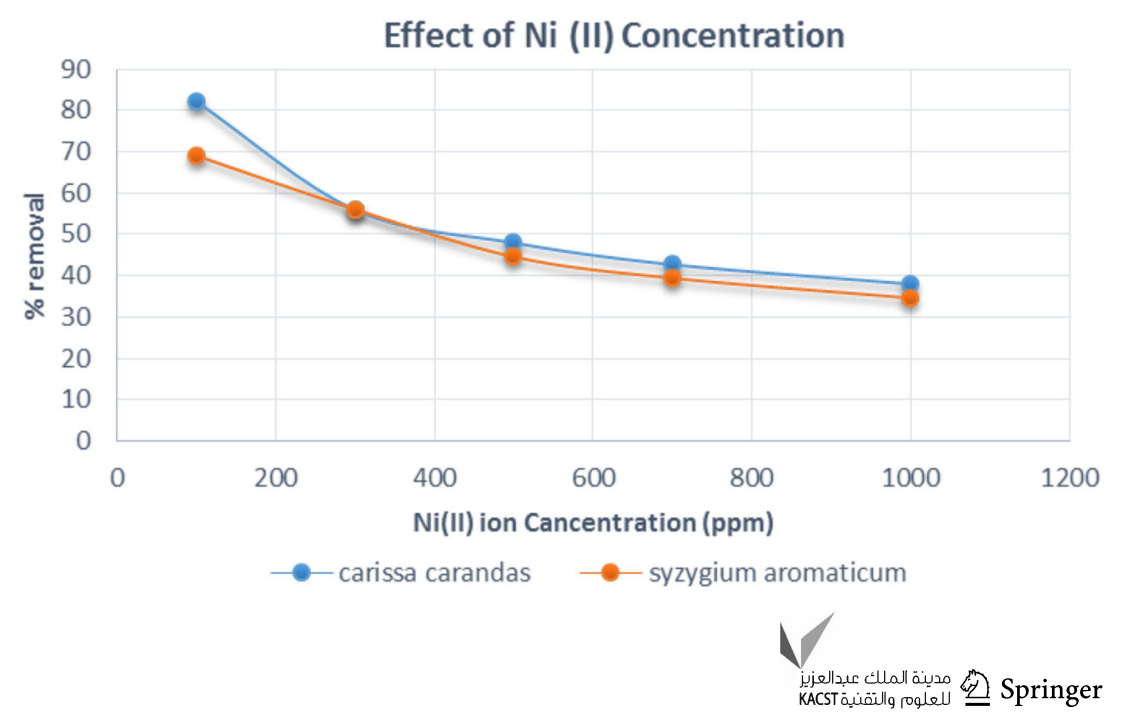


Table 4 Effect of initial metal concentration on biosorption of Ni(II)

\begin{tabular}{llll}
\hline S. No. & $\begin{array}{l}\text { Concentration of } \\
\text { metal }(\mathrm{mg} / 100 \mathrm{~mL})\end{array}$ & \multicolumn{2}{l}{ Removal of Ni(II) $(\%)$} \\
\cline { 3 - 4 } & & $\begin{array}{l}\text { Carissa } \\
\text { carandas }\end{array}$ & $\begin{array}{l}\text { Syzygium } \\
\text { aromaticum }\end{array}$ \\
\hline 1 & 100 & 82.22 & 69.23 \\
2 & 300 & 56.07 & 56.12 \\
3 & 500 & 48.12 & 44.56 \\
4 & 700 & 42.87 & 39.34 \\
5 & 1000 & 38.16 & 34.49 \\
\hline
\end{tabular}

Adsorbent dosage $=2 \mathrm{~g} / 100 \mathrm{~mL}$, contact time $=180 \mathrm{~min}, \mathrm{pH} 6$, $T=300 \mathrm{~K}$

equilibrium, respectively, and $Q_{0}(\mathrm{mg} / \mathrm{g})$ and $b(\mathrm{~L} / \mathrm{mg})$ are the Langmuir isotherm constants.

Kratochvil and Volesky (1998) suggested that high $Q_{0}$ and $b$ values indicate to good quality of biosorbents. The constants $b$ is related to monolayer adsorption capacity and energy of adsorption and the high values of constants indicating a high affinity of the adsorbate for the adsorbent.

The Freundlich isotherm model (Freundlich 1907) is as follows (Eq. 2)

$q_{\mathrm{e}}=K_{\mathrm{F}} C_{\mathrm{e}}^{n}$,

where $K_{\mathrm{F}}\left[\mathrm{mg} / \mathrm{g}(\mathrm{L} / \mathrm{g})^{1 / \mathrm{n}}\right]$ is the Freundlich constant related to the bonding energy, $n$ is the Freundlich exponent which depicts the extent of deviation from linearity of the adsorption.

Table 6 lists the calculated Freundlich and Langmuir isotherm constants. Based on regression coefficient $\left(R^{2}\right)$ values, the experimental data for adsorption of $\mathrm{Ni}(\mathrm{II})$ onto C. carandas and $S$. aromaticum powder fit better to Freundlich isotherm model than the Langmuir isotherm model. The adsorption of $\mathrm{Ni}$ (II) onto $C$. carandas was best described by the Freundlich isotherm model. The maximum adsorption capacities $\left(K_{\mathrm{L}}\right)$ estimated from the Freundlich isotherm model for $\mathrm{Ni}(\mathrm{II})$ were 3.76 and $2.96 \mathrm{mg} / \mathrm{g}$
Table 5 Effect of temperature on biosorption of Ni(II)

\begin{tabular}{llll}
\hline S. No. & Temperature $\left({ }^{\circ} \mathrm{C}\right)$ & \multicolumn{2}{l}{ Removal of $\mathrm{Ni}(\mathrm{II})(\%)$} \\
\cline { 3 - 4 } & & Carissa carandas & Syzygium aromaticum \\
\hline 1 & 20 & 56.76 & 52.12 \\
2 & 30 & 82.22 & 69.23 \\
3 & 40 & 69.17 & 65.91 \\
4 & 50 & 61.53 & 54.15 \\
\hline \multicolumn{5}{l}{$C_{0}=100 \mathrm{ppm}, \quad$ adsorbent } & dosage $=2 \mathrm{~g} / 100 \mathrm{~mL}$, & contact \\
time $=180 \mathrm{~min}, \mathrm{pH} 6$ & &
\end{tabular}

for $C$. carandas leaves and $S$. aromaticum, respectively (Figs. 8, 9).

\section{Adsorption kinetics}

Adsorption kinetic studies are important to determine the efficacy of adsorption. The purpose of adsorption kinetic studies is to investigate about the mechanism of biosorption and its potential rate-controlling steps that include mass transport and chemical reaction processes. In batch adsorption system, kinetic models such as pseudo-first order and pseudo-second order have been widely used. The linearized pseudo-first-order kinetic model takes the following form as

$q_{\mathrm{t}}=q_{\mathrm{e}}-q_{\mathrm{e}} \exp \left(-K_{1} t\right)$

$\log \left(q_{\mathrm{e}}-q\right)=\log q_{\mathrm{e}}-\frac{K_{1}}{2.303} t$,

where $q$ is the amount of $\mathrm{Ni}(\mathrm{II})(\mathrm{mg} / \mathrm{g})$ at time $t$ (minute), $q_{\mathrm{e}}$ is the amount of nickel adsorbed at equilibrium $(\mathrm{mg} / \mathrm{g}$ ) and $K_{1}$ is the equilibrium rate constant of pseudo-first order adsorption $\left(\min ^{-1}\right)$. The plot of $\log \left(q_{\mathrm{e}}-q_{\mathrm{t}}\right)$ versus $t$ gave a straight line for the first order adsorption kinetics.

The pseudo-second order kinetic model considered in this study is given as
Fig. 7 Effect of Temperature on biosorption of $\mathrm{Ni}(\mathrm{II})$; $\left(C_{0}=100 \mathrm{ppm}\right.$, dosage $=2 \mathrm{~g} /$

$100 \mathrm{~mL}$, contact

time $=180 \mathrm{~min}, \mathrm{pH}$ 6)

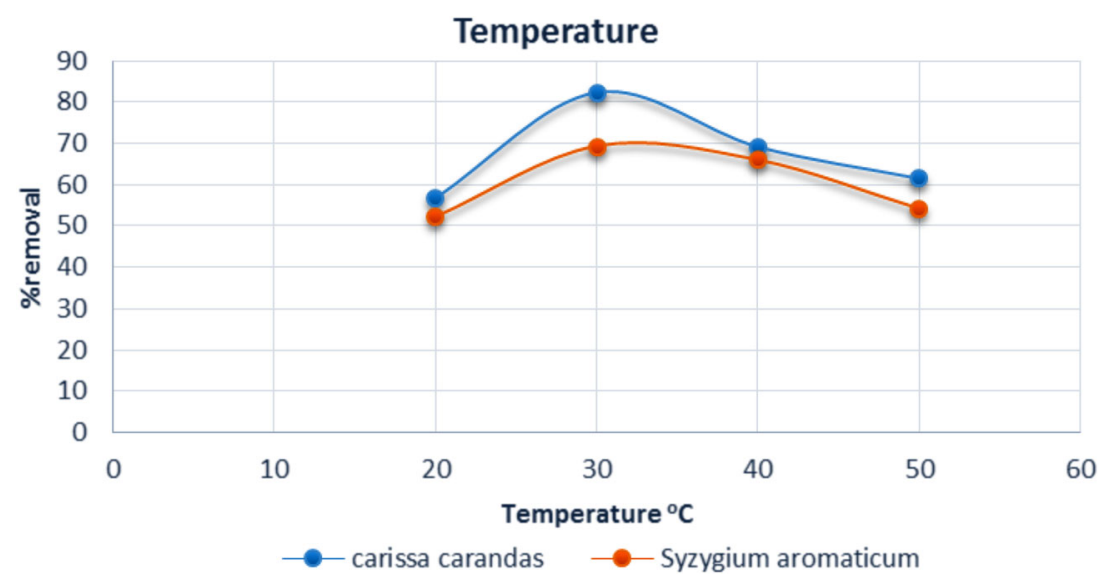


Table 6 Langmuir and freundlich isotherm constants for Ni(II) ion biosorption

\begin{tabular}{|c|c|c|c|c|c|c|}
\hline \multirow[t]{2}{*}{ Adsorbent } & \multicolumn{3}{|c|}{ Langmuir isotherm } & \multicolumn{3}{|c|}{ Freundlich isotherm } \\
\hline & $q_{\max }$ & $K_{\mathrm{L}}$ & $R^{2}$ & $K_{\mathrm{F}}$ & $N$ & $R^{2}$ \\
\hline Carissa carandas & 60.81 & 0.33 & 0.98 & 3.76 & 1.47 & 0.99 \\
\hline Syzygium aromaticum & 57.02 & 0.30 & 0.97 & 2.96 & 1.44 & 0.99 \\
\hline
\end{tabular}

Fig. 8 Freundlich isotherm for a $C$. carandas and $\mathbf{b} S$. aromaticum
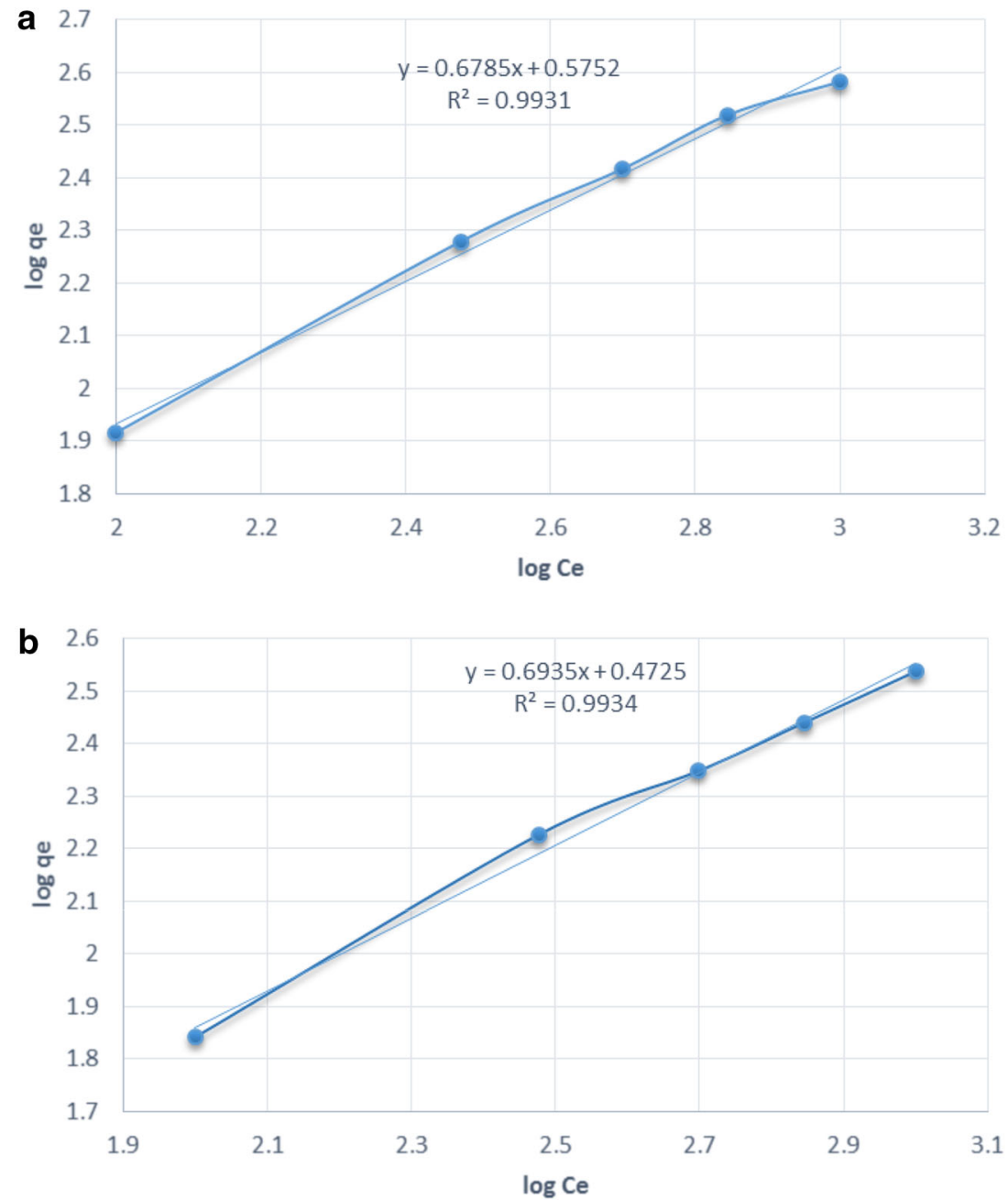

$\frac{1}{q_{\mathrm{t}}}=\frac{1}{k_{2} q_{\mathrm{e}}^{2}}+\frac{t}{q_{\mathrm{e}}}$,

where $K_{2}\left(\mathrm{~g} \mathrm{mg}^{-1} \mathrm{~min}^{-1}\right)$ is the second-order reaction rate constant.

The experimental data and the parameters of both models are reported in Table 7 . The coefficient of correlation $\left(R^{2}=0.99\right)$ for the pseudo-second-order kinetic model was higher in comparison with the pseudo-firstorder kinetic model and the kinetic data fits well with a pseudo-second order model for $\mathrm{Ni}(\mathrm{II})$ ion sorption as compared to a pseudo-first order model.

\section{SEM images}

The SEM images of adsorbents before and after adsorption are given in Figs. 10 and 11, respectively, for $C$. carandas and $S$. aromaticum. A significant difference in the appearance of the adsorbent surfaces could be noticed. 
Fig. 9 Langmuir isotherm for a $C$. carandas and $\mathbf{b} S$. aromaticum
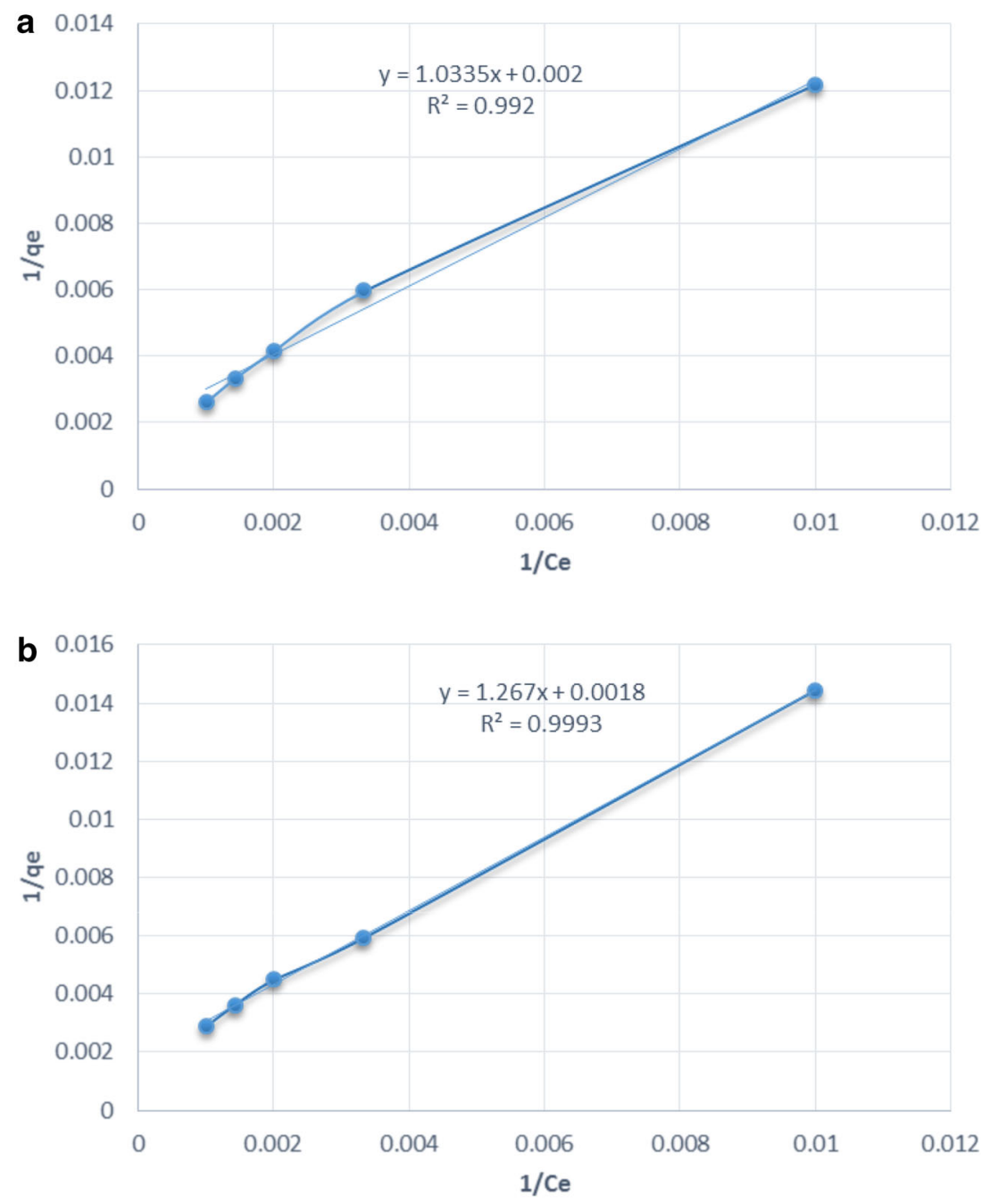

Table 7 Kinetics studies of biosption of Ni(II) on C. carandas and S. aromaticum

\begin{tabular}{|c|c|c|c|c|c|c|c|c|}
\hline \multirow[t]{2}{*}{ Biosorbent } & \multirow{2}{*}{$\begin{array}{l}\text { Metal ion } \\
\text { concentration } \\
(\mathrm{ppm})\end{array}$} & \multirow{2}{*}{$\begin{array}{l}q_{\mathrm{e}}, \exp \\
(\mathrm{mg} / \mathrm{g})\end{array}$} & \multicolumn{3}{|c|}{ Pseudo-first-order kinetic model } & \multicolumn{3}{|c|}{ Pseudo-second-order kinetic model } \\
\hline & & & $q_{\mathrm{e}, \mathrm{cal}}(\mathrm{mg} / \mathrm{g})$ & $K_{1}\left(\min ^{-1}\right)$ & $R^{2}$ & $q_{\mathrm{e}, \mathrm{cal}}(\mathrm{mg} / \mathrm{g})$ & $K_{2}\left(\mathrm{~g} \mathrm{mg}^{-1} \min ^{-1}\right)$ & $R^{2}$ \\
\hline \multirow[t]{5}{*}{ Carissa carandas } & 100 & 4.11 & 36.96 & $4.60 \times 10^{-3}$ & 0.92 & 105.26 & $1.6 \times 10^{-4}$ & 0.99 \\
\hline & 300 & 8.4 & 99.48 & $2.99 \times 10^{-3}$ & 0.95 & 185.18 & $1.9 \times 10^{-4}$ & 0.99 \\
\hline & 500 & 12.03 & 177.68 & $1.84 \times 10^{-3}$ & 0.96 & 256.41 & $2.5 \times 10^{-4}$ & 0.99 \\
\hline & 700 & 15.00 & 249.63 & $9.21 \times 10^{-4}$ & 0.96 & 312.5 & $3.9 \times 10^{-4}$ & 0.99 \\
\hline & 1000 & 19.08 & 307.96 & $1.15 \times 10^{-3}$ & 0.96 & 400 & $2.6 \times 10^{-4}$ & 0.99 \\
\hline \multirow[t]{5}{*}{ Syzygium aromaticum } & 100 & 3.46 & 36.96 & $3.68 \times 10^{-3}$ & 0.91 & 83.33 & $3.0 \times 10^{-4}$ & 0.99 \\
\hline & 300 & 8.41 & 120.30 & $1.84 \times 10^{-3}$ & 0.95 & 181.81 & $3.1 \times 10^{-4}$ & 0.99 \\
\hline & 500 & 11.14 & 169.01 & $1.38 \times 10^{-3}$ & 0.95 & 232.58 & $3.3 \times 10^{-4}$ & 0.99 \\
\hline & 700 & 13.76 & 228.14 & $1.15 \times 10^{-3}$ & 0.94 & 285.71 & $3.9 \times 10^{-4}$ & 0.99 \\
\hline & 1000 & 17.24 & 281.46 & $1.15 \times 10^{-3}$ & 0.96 & 357.14 & $3.0 \times 10^{-4}$ & 0.99 \\
\hline
\end{tabular}


Fig. 10 SEM image of $C$. carandas a before Adsorption; b after Adsorption
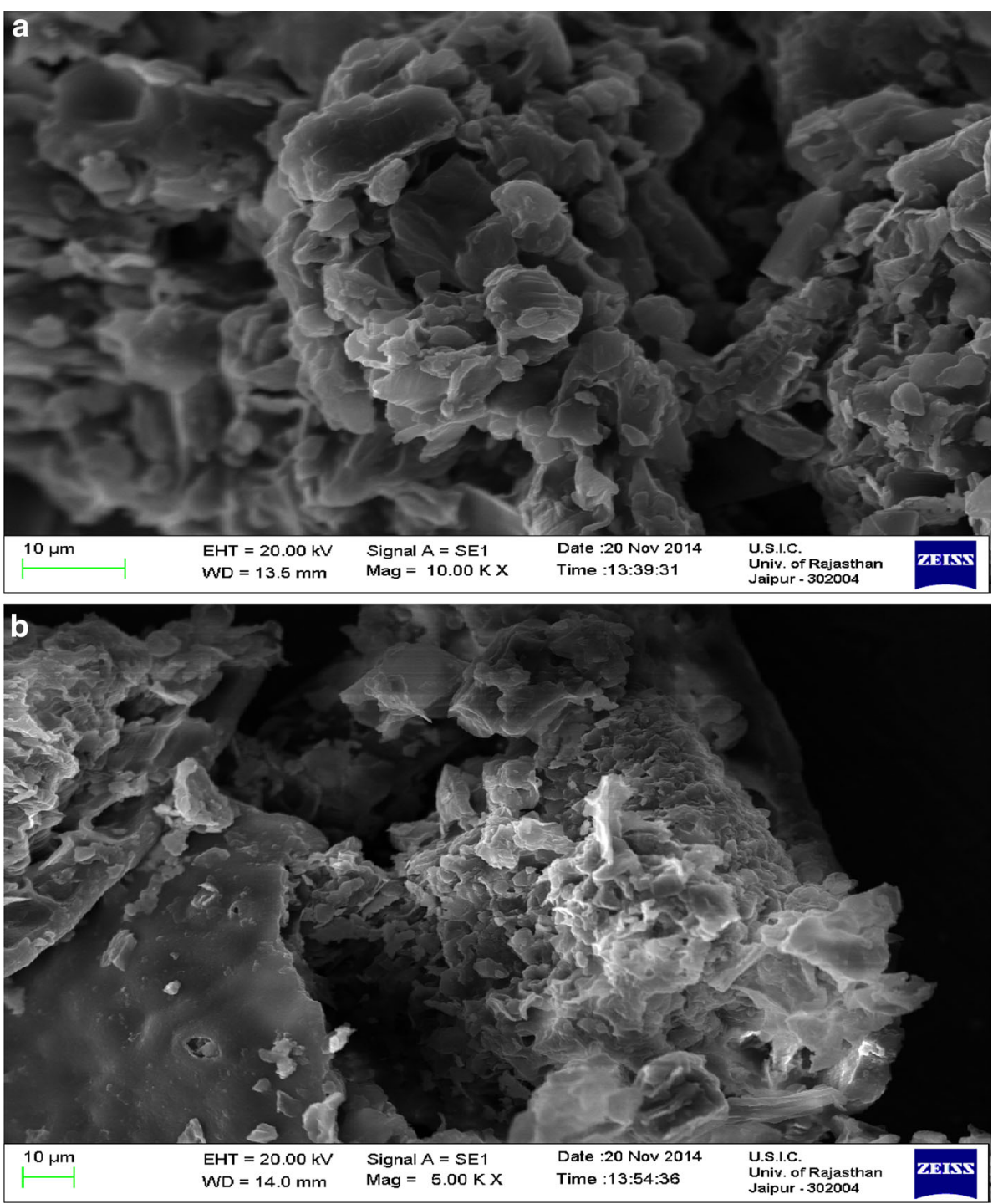

Images clearly highlight the action of adsorption on the surfaces of both the adsorbents and strengthen the view point of the researchers.

\section{Conclusions}

This study was focused on the biosorption of $\mathrm{Ni}(\mathrm{II})$ ion onto of $C$. carandas and $S$. aromaticum biomass from aqueous solution. The operating parameters, $\mathrm{pH}$ of solution, biomass dosage, contact time, initial metal ion concentration, and temperature were effective on the biosorption efficiency of $\mathrm{Ni}(\mathrm{II})$. Biosorbent $C$. carandas leaf powder showed higher sorption efficiency than that of biosorbent $S$. aromaticum powder under identical experimental conditions. Adsorption isotherm studies revealed that the Freundlich isotherm model showed a better experimental data in comparison of the Langmuir isotherm model. The maximum adsorption capacities estimated from Freundlich isotherm model for $\mathrm{Ni}(\mathrm{II})$ were 3.76 and $2.96 \mathrm{mg} / \mathrm{g}$ for $C$. carandas and $S$. aromaticum, respectively.

Since, several parameters including migration of metal ions from bulk solution to the surface of the adsorbent through bulk diffusion and the adsorption of metal ions at an active site on the surface of the adsorbent by chemical 
Fig. 11 SEM image of $S$. aromaticum a before Adsorption; b after Adsorption
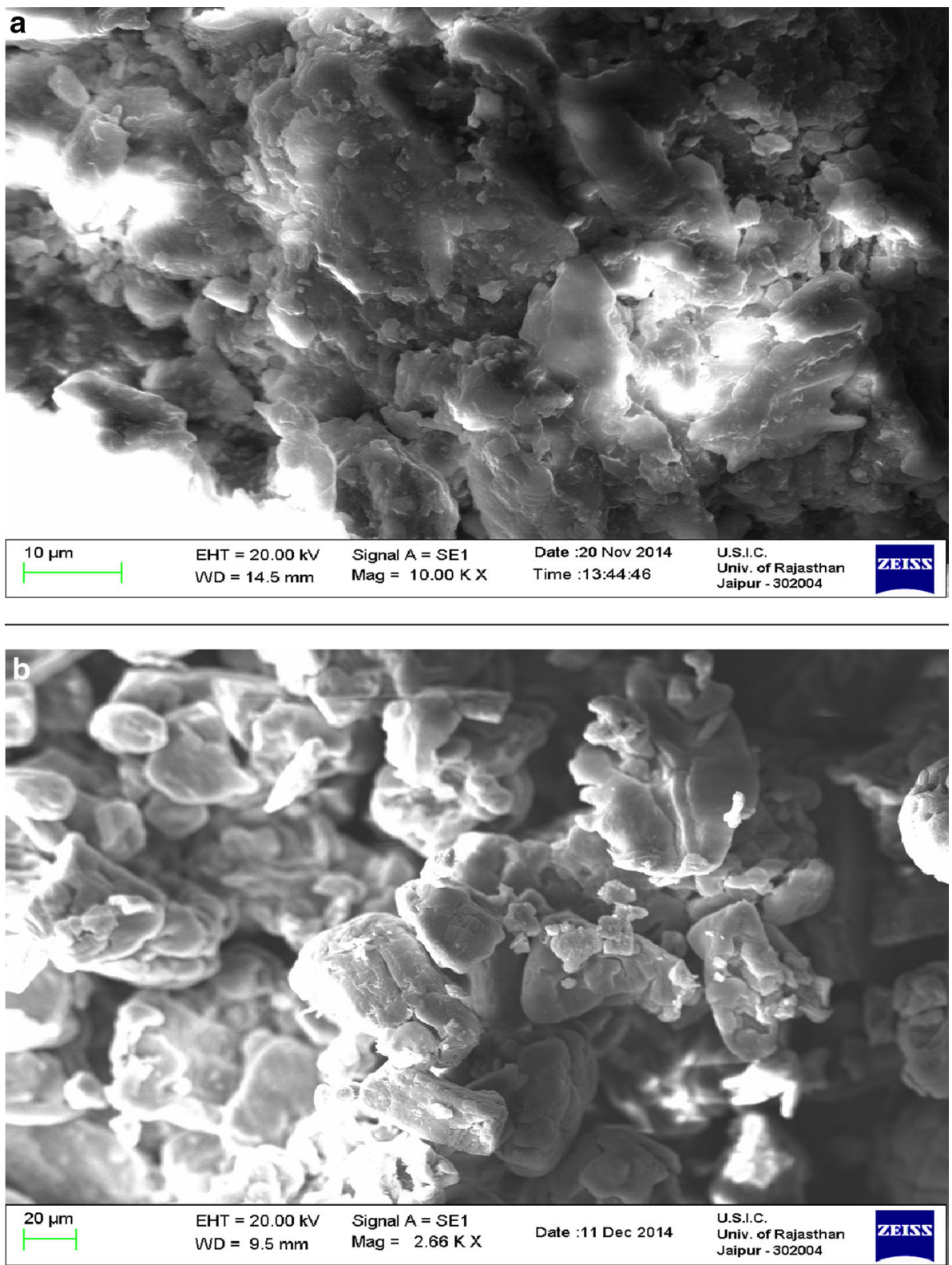

reactions play very important role in deciding the adsorption kinetics and adsorption mechanism; the actual adsorption mechanism is yet to be discussed and explained.

Acknowledgments Author (SM) thankfully acknowledge the scholarship given by President, JECRC University for his Ph.D. work. $\mathrm{He}$ is also grateful to USIC, University of Rajasthan, Jaipur, and the Team Institute of Science and Technology, Jaipur for providing analytical help for the work presented in this paper.

Open Access This article is distributed under the terms of the Creative Commons Attribution 4.0 International License (http:// creativecommons.org/licenses/by/4.0/), which permits unrestricted use, distribution, and reproduction in any medium, provided you give appropriate credit to the original author(s) and the source, provide a link to the Creative Commons license, and indicate if changes were made.

\section{References}

Ahmed S, Khalid N, Dand M (2002) Adsorption studies of lead minerals from aqueous media. Sep Sci Technol 37:343-362

Aikpokpodion P, Ipinmoroti R, Omotoso S (2010) Biosorptionof nickel(II) from aqueous solution using wastetea (Camella cinencis) materials. Am Eurasian J Toxicol Sci 2:72-82

Ajay Kumar AV, Darwish NA, Hilal N (2009) Study of various parameters in the biosorption of heavy metals on activated sludge. World Appl Sci J 5:32-40

Akhtar N, Iqbal J, Iqbal M (2004) Removal and recovery of nickel(II) from aqueous solution by loofa sponge-immobilized biomass of Chlorella sorokiniana: characterization studies. J Hazard Mater 108:85-94

Aksu Z, Dönmez G (2006) Binary biosorption of cadmium(II) and nickel(II) onto dried Chlorella vulgaris: co-ion effect on monocomponent isotherm parameters. Process Biochem 41:860-868 
Alejandro HE, Eliseo CU (2014) Nickel(II) biosorption from aqueous solutions by shrimp head biomass. Environ Monit Assess 186:7987-7998. doi:10.1007/s10661-014-3981-5

Ankur G, Chandrajit B (2015) Simultaneous removal of Cr(VI) and phenol from synthetic binary solution using consortium culture of Bacillus sp. and E. coli immobilized on tea waste biomass in packed bed reactor. Korean J Chem. doi:10.1007/s11814-0150137-4

Buerge-Weirich D, Hari R, Xue H, Behra P, Sigg L (2002) Adsorption of $\mathrm{Cu}, \mathrm{Cd}$, and $\mathrm{Ni}$ on goethite in the presence of natural groundwater ligands. Environ Sci Technol 36:328-336

Canet L, Ilpide M, Seat P (2002) Efficient facilitated transport of lead, cadmium, zinc and silver across a flat sheet-supported liquid membrane mediated by lasalocid A. Sep Sci Technol 37:1851-1860

Chamila G, Kandanapitiye MS, Dudarko O, Huang DS, Jaroniec M (2015) Adsorption of lead ions from aqueous phase on mesoporous silica with P-containing pendant groups. ACS Appl Mater Interfaces. doi:10.1021/acsami.5b06951

Chandrawat MPS, Gupta J, Mudhoo A, Sharma SK (2009a) Investigations of hygienic state of drinking water at different tourist places of Alwar District of Rajasthan (India). Asian J Water Environ Pollut 6:101

Chandrawat MPS, Gupta J, Sharma SK, Mudhoo A (2009b) Study of Chemical Status and quality assessment of drinking water in Alwar District (Rajasthan, India). Int J Process Wastes Treat 1(1):27-56

Denkhaus E, Salnikow K (2002) Nickel essentiality, toxicity, and carcinogenicity. Crit Rev Oncol Hematol 42:35-56

Esalah JO, Weber ME, Vera JH (2000) Removal of lead, cadmium and zinc from aqueous solutions by precipitation with sodium di(n-octyl) phosphinate. Can J Chem Eng 78:948-954

Freundlich H (1907) Ueber die adsorption in Loesungen. Z Physik Chem 57:385-470

Gautam RK, Chatopadhyay MC, Sharma SK (2012) Biosorption of heavy metals: recent trends and challenges. In: Sharma SK, Sanghi R (eds) Waste water reuse and management. Springer, New York, pp 305-322

Gautam RK, Sharma SK, Mahiya S, Chattopadhyay MC (2014) Contamination of heavy metals in aquatic media: transport, toxicity and technologies for remediation. In: Sharma SK (ed) Heavy metals in water: presence removal and safety. Royal Society of Chemistry Publications, London

Grassi M, Kaykioglu G, Belgiorno V, Lofrano G (2012) Removal of emerging contaminants from water and wastewater by adsorption process. In: Lofrano $\mathrm{G}$ (ed) Emerging compounds removal from wastewater. Natural and solar based treatments. Springer, New York, ISBN 978-9-4007-3915-4

Ho YS, Ng JCY, McKay G (2001) Removal of lead(II) from effluents by sorption on peat using second-order kinetics. Sep Sci Technol 36:241-261

Hossein SGRM, Leila I, Gholam AM, Elham A (2015) Removal of $\mathrm{Cr}(\mathrm{VI})$ from synthetic aqueous solutions by filamentous green algae Spirogyra porticalis. Desalination Water Treat. doi:10. 1080/19443994.2015.1090921

Kaushik N, Kaushik CP, Sharma SK, Sharma JK (2007) Pollution hazards in polyester dyeing and role of acid in monitoring. Curr World Environ 2(2):175-182

Khan MA, Alemayehu A, Duraisamy R, Berekete AK (2015) Removal of Lead ion from aqueous solution by Bamboo activated Carbon. Int J Water Res 5:33-46

Kratochvil D, Volesky B (1998) Advances in the biosorption of heavy metals. Trends Biotechnol 16:291-300

Kulshrestha S, Sharma SK, Singh RV (2004) Impact of Domestic and Industrial Effluents on Water and Soil Quality of Sanganer of 'Heritage City', Jaipur. Int J Chem Sci 2(1):27-36
Langmuir I (1918) The adsorption of gases on plane surfaces of glass, mica and platinum. J Am Chem Soc 40:1361-1403

Libralato G, Avezzù F, Losso C, Volpi Ghirardini A (2009a) Influence of storage methods, refrigeration or freezing, on the toxicity of wastewater samples to oyster embryos. Environ Technol 30:535-541

Libralato G, Losso C, Avezzù F, Volpi Ghirardini A (2009b) Influence of salinity adjustment methods, salts and brine, on the toxicity of wastewater samples to mussels embryos. Environ Technol 30:85-91

Libralato G, Volpi Ghirardini A, Avezzù F (2010a) How toxic is toxic? A proposal for wastewater toxicity hazard assessment. Ecotoxicol Environ Saf 73:1602-1611

Libralato G, Volpi Ghirardini A, Avezzù F (2010b) Seawater ecotoxicity of monoethanolamine, diethanolamine and triethanolamine. J Hazard Mater 176:535-539

Ma W, Gao LL, Cheng ZH, Wang R, Liu FJ, Liu DM, Pan DC (2014) Biosorption of nickel ions by modified chitosan from aqueous solutions. Appl Mech Mater 472:835-839

Mahiya S, Lofrano G, Sharma SK (2014) Biosorptive removal of copper(II) from aqueous solution by using Syzygium aromaticum and Carissa carandas. Chem Sci Trans 3:1228-1241

Mondal DK, Nandi BK, Purkait MK (2013) Removal of mercury(II) from aqueous solution using bamboo leaf powder: equilibrium, thermodynamic and kinetic studies. J Environ Chem Eng 1:891-898

Mudhoo A, Sharma SK (2011) Microwave irradiation technology in waste sludge and wastewater treatment research. Crit Rev Environ Sci Technol 41(11):999-1066

Mudhoo A, Munbodh VP, Ragen AK, Garg VK, Sharma SK (2009) Anaerobic treatment of tuna processing wastewater in an Upflow Anaerobic Contact reactor. Int $\mathrm{J}$ Process Wastes Treat 1(1):83-97

Muhammad NZ, Iqra A, Raziya N, Shahida M, Usman AR, Salah UDK (2015) Characterization of chemically modified biosorbents from rice bran for biosorption of $\mathrm{Ni}(\mathrm{II})$. J Taiwan Inst Chem Eng 46:82-88. doi:10.1016/j.jtice.2014.08.034

Ozha DD, Sharma SK (2011) Mitigation of Water Quantity and Water Quality Challenges in Groundwater of Rajasthan. Water Res Dev $1(1): 45-52$

Pankaj KP, Sharma SK, Sambi SS (2015) Removal of lead(II) from waste water on zeolite-NaX. J Environ Chem Eng. doi:10.1016/j. jece.2015.09.008

Rani R, Jain S, Sharma SK (2011) Nano-catalyst: a second generation tool for Green Chemistry. In: Sanghi R, Singh V (eds) Green Chemistry for environmental remediation. Scrivener Publishing LLC, Massachusetts, pp 357-378

Ravindran V, Stevens MR, Badriyha BN, Pirbazari M (1999) Modeling the sorption of toxic metals on chelant-impregnated adsorbent. AIChE J 45:1135-1146

Rifaqat AKR, Shaista I (2015) Adsorption studies of $\mathrm{Cu}(\mathrm{II}), \mathrm{Ni}(\mathrm{II})$ and $\mathrm{Zn}$ (II) on Ajwain (Trachyspermum copticum), a medicinal plant. Int J Environ Eng 7:179-203. doi:10.1504/IJEE.2015. 069809

Saleem M, Wongsrisujarit N, Boonyarattanakalin S (2015) Removal of nickel(II) ion by adsorption on coconut copra meal biosorbent. Desalination Water Treat. doi:10.1080/19443994.2015.1005155

Sanghi R, Singh V, Sharma SK (2011) Environment and the role of Green Chemistry. In: Sanghi R, Singh V (eds) Green Chemistry for environmental remediation. Scrivener Publishing LLC, Massachusetts, pp 3-34

Sefath UK, Farman UK, Ihsan UK, Nawshad M, Syed B, Adnan K, Asim U, Amir SK, Hazrat B, Asma N (2014) Biosorption of nickel(II) and copper(II) ions from aqueous solution using novel biomass derived from Nannorrhops ritchiana (Mazri Palm). Desalination Water Treat. doi:10.1080/19443994.2014.98926

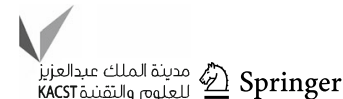


Sharma SK (2003) Physicochemical characterization and quality analysis of underground water in Matsya Industrial Area of Alwar city. Nat Environ Pollut Tech 2(4):493-495

Sharma SK, Choudhary A, Singh RV (2008) Gray chemistry verses Green Chemistry: challenges and opportunities. Rasayan J Chem $1: 68$

Sharma SK, Mudhoo A, Zhang W (2010) Green Chemistry and engineering: a versatile research perspective. In: Sharma SK, Mudhoo A (eds) Green Chemistry for environmental sustainability. Taylor \& Francis Group, LLC, Florida, pp 1-52

Sharma SK, Sanghi R, Mudhoo A (2012) Green practices to save our precious 'water resource'. In: Sharma SK, Sanghi R (eds) Advances in water treatment and pollution prevention. Springer, New York, pp 1-36

Silverstein RM, Bassler GC, Morrill TC (1981) Spectrometric identification of organic compounds. Wiley, New Jersey, pp 95-105

Volesky B (2001) Detoxification of metal-bearing effluents: biosorption for the next century. Hydrometallurgy 59:203-216
World Health Organization (2006) Guidelines for drinking-water quality, Incorporating First addendum to third Edition, 3rd edn, vol 1. WHO Press, Geneva

Yadav R, Yadav RN, Chandrawat MPS, Sharma SK (2008) Assessment of fluoride content, $\mathrm{pH}$ and TDS in potable water of alwar city: an environmental concern. Rasâyan J Chem 1(4):929-935

Yadav AK, Khan P, Sharma SK (2010) Water quality index assessment of groundwater in Todaraisingh Tehsil of Rajasthan State, India-a greener approach. J Chem 7(S1):S428-S432

Yadav AK, Khan P, Ojha KG, Sharma SK (2011) N-Content in groundwater of todaraishing area of Tonk District, Rajasthan, India. Water Res Dev 1(1):20-26

Yuvaraja G, Venkata SM, Naushad M, Krishnaiah A (2015) Removal of $\mathrm{Ni}$ (II) from aqueous solution by Lycopersicum esculentum (Tomato) leaf powder as a low-cost biosorbent. Desalination and Water Treat. doi:10.1080/19443994.2014.880160

Zouboulis AI, Matis KA, Lanara BG, Neskovic CL (1997) Removal of cadmium from dilute solutions by hydroxy apatite. II. Floatation studies. Sep Sci Technol 32:1755-1767 